\title{
ANALISIS PENDAPATAN SUPIR PARIWISATA FREELANCE/ INFORMAL PASCA TRANSPORTASI ONLINE DI WILAYAH SARBAGITA PROVINSI BALI
}

\author{
A.A. Bagus Putu Widanta ${ }^{1}$, I Wayan Wita Kesumajaya ${ }^{2}$ \\ ${ }^{1}$ Email: agung_widanta@yahoo.com \\ ${ }^{1,2}$ Fakultas Ekonomi dan Bisnis, Universitas Udayana
}

\begin{abstract}
The development process indirectly accelerated the transformation process, Bali as one of the provinces in Indonesia also experienced a change from agrarian to industrial which was indicated by the contribution of the agricultural sector to decreasing the GDRP of Bali. Bali tourism continues to experience growth every year, which is marked by the number of tourist visits that increase every year. Rapid tourism growth requires supporting infrastructure for the needs of tourists while in Bali such as accommodation, restaurants, adequate roads, tourism objects, financial services, supply of goods and transportation services. Transportation services sector is an important requirement for tourists both for tourism and business purposes. Tourists visiting Bali Province can use a choice of public transportation modes such as bemo, Sarbagita bus, taxi and turtle transportation. The choice of transportation chosen is usually adjusted to the needs and destination. Rapidly Growing of tourism attracts many workers in Bali who are not accommodated in the formal sector to benefit the blessings of Tourism, with the limitation of capital to meet the needs of life and family needs as an informal tourism driver / freelance driver. The exsistence of freelance drivers with uncertain daily income due to intense competition, the more severe challenges in the future with the presence of online transport / taxis. Online transportation with all its advantages gets strong reactions and rejection from conventional transportation (bemo,taxi, and informal tourism driver) some of them end with the dispute. This study is not only aimed to analyzing the factors that influence the income of freelance drivers, but also examines how the influence of the presence of online transport / taxis influencing the income of freelance drivers. Primary data is used as the main estimate, with a sample of freelance tourism drivers in the Sarbagita Region of Bali Province. Estimates using a multiple linear regression models with independent variables in the form of dummy variables. The estimation results provide a complete picture of the factors that influence the income of freelance tourism drivers in the Sarbagita region of Bali Province. The results also provide an overview income of freelance drivers after the emergence of online transportation. The results of the study are also expected to be a reference for sharing parties in an effort to reduce the friction that occurs.
\end{abstract}

\begin{abstract}
Abstrak: Proses pembangunan secara tidak langsung mempercepat proses transformasi, Bali sebagai salah satu provinsi di Indonesia juga mengalami perubahan dari agraris ke industri yang ditunjukkan oleh kontribusi sektor pertanian terhadap penurunan PDRB Bali. Pariwisata Bali terus mengalami pertumbuhan setiap tahun, yang ditandai dengan jumlah kunjungan wisatawan yang meningkat setiap tahun. Pertumbuhan pariwisata yang cepat membutuhkan infrastruktur pendukung untuk kebutuhan wisatawan sementara di Bali seperti akomodasi, restoran, jalan yang memadai, objek wisata, layanan keuangan, pasokan barang dan jasa transportasi. Sektor jasa transportasi merupakan syarat penting bagi wisatawan baik untuk keperluan pariwisata maupun bisnis. Wisatawan yang mengunjungi Provinsi Bali dapat menggunakan pilihan moda transportasi umum seperti bemo, bus Sarbagita, taksi, dan transportasi penyu. Pilihan transportasi yang dipilih biasanya disesuaikan dengan kebutuhan dan tujuan. Pesatnya pertumbuhan pariwisata menarik banyak pekerja di Bali yang tidak ditampung di sektor formal untuk mendapatkan manfaat berkah dari Pariwisata, dengan keterbatasan modal untuk memenuhi kebutuhan hidup dan kebutuhan keluarga sebagai sopir pariwisata informal/pengemudi lepas. Keberadaan pengemudi freelance dengan pendapatan harian yang tidak pasti karena persaingan yang ketat, tantangan yang lebih berat di masa depan dengan kehadiran transportasi online/taksi. Transportasi online dengan segala kelebihannya mendapat reaksi keras dan penolakan dari transportasi konvensional (bemo, taksi, dan sopir pariwisata informal) beberapa di antaranya berakhir dengan perselisihan. Penelitian ini tidak hanya bertujuan untuk menganalisis faktor-faktor yang
\end{abstract}


mempengaruhi pendapatan pengemudi freelance, tetapi juga meneliti bagaimana pengaruh keberadaan transportasi online/taksi yang mempengaruhi pendapatan pengemudi freelance. Analisis data menggunakan model regresi linier berganda dengan variabel independen dalam bentuk variabel dummy. Hasil estimasi memberikan gambaran lengkap tentang faktor-faktor yang mempengaruhi pendapatan pengemudi pariwisata lepas di wilayah Sarbagita Provinsi Bali. Hasilnya juga memberikan gambaran umum pendapatan pengemudi freelance setelah kemunculan transportasi online. Hasil penelitian ini juga diharapkan dapat menjadi referensi untuk berbagi pihak dalam upaya mengurangi gesekan yang terjadi.

Keywords: income, informal driver, freelance, online transport.

\section{PENDAHULUAN}

Bali sebagai salah satu provinsi yang ada di Indonesia juga mengalami perubahan dari agraris ke industri. Hal tersebut dapat diindikasikan pula dari sumbangan sektor pertanian terhadap PDRB Bali yang semakin berkurang, pada tahun 2016 seperti pada gambar sumbangan sektor pertanian hanya sebesar 14,74 persen terhadap PDRB Provinsi Bali. diringi sumbangan sektor-sektor lain yang terus meningkat setiap tahunnya. Provinsi Bali tidak memiliki kekayaan alam seperti tambang dan migas sehingga pabrik pabrik besar tidak berkembang di Bali, namun Bali memiliki potensi yang sangat besar di sektor Pariwisata, diindikasikan sumbangan akomodasi dan makanan terhadap PDRB Provinsi yang paling tinggi yakni sebesar 22,82 persen. Bali yang kaya akan beragam seni budaya dan terkenal pula dengan berbagai macam keindahan pemandangan alamnya, sejarah festval dan beragam upacara-upacara yang unik menjadi daya tarik wisatawan baik domestik maupun mancanegara untuk datang berkunjung.
Keramahan dan sopan santun penduduk yang memberikan rasa nyaman kepada pengunjung juga memberikan kontribusi positif terhadap jumlah kunjungan wisatawan ke Bali.

Pariwisata Bali sudah berkembang sebelum kemerdekaan, dapat ditelusuri semenjak kedatangan pelaut belanda ke Bali pada tahun 1597, inilah kontak pertama orang Bali dengan orang eropa. Ketika kapten kapal Cornelius Houtman ingin meninggalkan Bali, banyak awak kapal yang tidak ingn meninggalkan Bali. Mereka sangat terpesona dan tidak ingin meninggalkan pulau Bali. Pra kemerdekaan pariwisata Bali dimulai dari desa Ubud kabupaten Gianyar pada tahun 1930, dimana banyak seniman asing yang memilih menetap di kawawasan tersebut. Pariwisata terus berkembang pada tahun 1963, ditandai dengan berdirinya hotel Bali Beach dipantai Sanur kota Denpasar menjadi nodal berkembangnya pariwisata disekitarnya. Jumlah wisatawan yang berkunjung ke Bali terus meningkat setiap tahunnya.

Tabel 1. Perkembangan Kunjungan Wisatawan Ke Bali

\begin{tabular}{ccccc}
\hline Tahun & Mancanegara & $\begin{array}{c}\text { Perkembangan } \\
(\boldsymbol{\%})\end{array}$ & Nusantara & $\begin{array}{c}\text { Perkembangan } \\
(\boldsymbol{\%})\end{array}$ \\
\hline 2012 & 2.892 .019 & 4,91 & 6.063 .558 & 6,84 \\
2013 & 3.278 .598 & 13,37 & 6.976 .536 & 15,06 \\
2014 & 3.766 .638 & 14,89 & 6.394 .307 & $-8,35$ \\
2015 & 4.001 .835 & 6,24 & 7.147 .100 & 11,77 \\
2016 & 4.927 .937 & 23,14 & 8.643 .680 & 20,94 \\
\hline
\end{tabular}

Sumber: Dinas Pariwisata Provinsi Bali, 2017.

Berkembangnya sektor pariwisata sebagai leading sector otomatis mendorong sektor -sektor lain seperti; sektor jasa, manufaktur termasuk angkutan untuk ikut tumbuh dan berkembang.. Pertumbuhan pariwisata yang pesat memerlukan infrastruktur pendukung untuk kebutuhan wisatawan selama berada di Bali seperti akomodasi, restoran, jalan raya memadai, obyek wisata, pelayanan jasa keuangan, pasokan hasil pertanian dan jasa angkutan.

Sektor jasa angkutan menjadi kebutuhan yang penting bagi Wisatawan untuk bepergian mengunjungi obyek wisata 
maupun mendatangi tempat untuk keperluan lain. Sumbangan sektor angkutan dan pergudangan terhadap PDRB Provinsi Bali yang sebesar 9,48 persen mengindikasikan sektor ini terus tumbuh dan berkembang dan memiliki potensi untuk digali dan dikembangkan. Perjalanan wisata didominasi oleh usaha perjalanan wisata formal mulai dari biro perjalanan umum (travel agent), Selain Travel agen, wisatawan yang berkunjung ke Provinsi menggunakan pilihan moda transportasi lain seperti angkutan umum seperti bemo, bus Sarbagita, taxi dan angkutan kura-kura. Pilihan transportasi yang dipilih biasanya disesuaikan dengan kebutuhan dan tempat tujuannya.

Transport freelance menjadi alternatif transportasi wisatawan selama berada di Bali, tidak sedikit tenaga kerja Bali yang menghidupi keluarganya dari pekerjaan sebagai supir freelance yang tidak terikat dengan Biro Perjalanan Wisata. Mereka menjadikan pekerjaan sebagai supir freelance baik sebagai pilihan maupun karena keadaan karena tidak tertampung di sektor formal. Menurut I Made Santha Kepala Dinas Perhubungan ,Informasi dan Komunikasi Provinsi Bali, memperkirakan jumlah angkutan wisata di Bali terdapat 6000 unit kendaraan angkutan wisata yang belum berijin beroperasi di Bali. (Detik News, 2001).

Kemajuan Iptek dan globalisasi memberikan dampak terhadap Pariwisata Bali termasuk di sektor angkutan. Transaksi dan perdagangan konvensional mulai digantikan dengan perdagangan secara elektronik atau online. Dikota- kota besar di Indonesia umumnya dan di Bali khususnya wilayah Sarbagita (kota denpasar, kabupaten Tabanan, Kabupaten Gianyar dan Kabupaten Badung) mulai muncul keberadaan transportasi Online seperti: Gojek, Grab dan Uber. Keberadaan transportasi online disambut pro dan kontra dimasyarakat. Disatu sisi terjadi penolakan oleh pelaku transportasi konvensional yang sudah ada sebelumnya. Dari awal kemunculan tranportasi online menimbulkan banyak pergesekan dan perselisihan dengan transportasi konvensional termasuk transportasi freelance, tidak sedikit perselisihan yang berakhir dengan tindakan pidana.

Disisi lain animo penerimaan yang besar dari masyarakat luas terhadap moda transportasi baru ini. Transportasi online seolah menjawab kebutuhan masyarakat akan transportasi yang murah, mudah dan cepat. Transportasi/ taxi online akhirnya memiliki kepastian hukum dan diatur melalui Peraturan Menteri Perhubungan no 26 tahun 2017 dan akan diperbaharui dengan Peraturan Menteri Perhubungan no 108 tahun 2017 tentang penyelenggaraan angkutan orang dengan kendaraan bermotor tidak dalam trayek.

Keberadaan supir freelance yang pendapatannya tidak menentu setiap harinya dengan persaingan yang ketat dari transportasi formal, semakin berat tantangan kedepannya dengan keberadaan transport/ taksi online. Tingkat pendapatan supir freelance tidak hanya dipengaruhi oleh persaingan semata, namun banyak faktor yang mempengaruhi, sehingga diperlukan penggalian informasi yang komprehensif mengenai faktor yang mempengaruhi pendapatan supir freelance. Pada penelitian ini akan diuji mengenai factor-faktor yang berpengaruh terhadap pendapatan supir freelance di Wilayah Sarbagita.

Selain persaingan yang semakin ketat, empat faktor produksi juga mempengaruhi pendapatan supir freelance, tanah/ sumberdaya alam tidak hanya dalam bentuk fisik tetapi juga non fisik bisa dikaitkan dengan lokasi/tempat mangkal supir freelance untuk menunggu calon penumpang wisatawan. Modal juga merupakan faktor produksi yang tidak kalah penting. Dengan modal yang dimiliki memungkinkan supir Freelance untuk memiliki unit kendaraannya sendiri yang akan membebaskan supir freelance dari biaya sewa kendaraan. Modal yang lebih besar memungkinkan supir freelance untuk memiliki kendaraan yang lebih besar, lebih mewah dan lebih baru. sehingga kesempatan memperoleh pendapatan lebih besar akan lebih mudah dicapai. Tenaga kerja/ sumberdaya yang dimanfaatkan secara optimum akan menghasilkan output/produksi yang lebih optimal. Supir freelance yang jam kerjanya lebih lama dan berpengalaman dibandingkan dengan yang lain memungkinkan untuk mendapatkan pendapatan yang lebih besar. Skill/ keahlian seseorang juga memberikan dampak yang besar bagi seseorang untuk memperoleh pendapatan yang lebih besar. Tenaga kerja yang cakap yang memiliki skill yang 
diperoleh melalui pendidikan ataupn pelatihan maupun pengalaman akan lebih diterima di pasar kerja. Kemajuan teknologi bisa meningkatkan produktivitas manusia maupun produktivitas kapital (Boediono, 1999). Pemanfaatan kemajuan informasi dan Teknologi (IT) memungkinkan seseorang untuk mempromosikan produknya dan memberikan informasi yang cukup kepada calon pelanggan. Pada survey awal yang dilakukan peneliti, ditemukan ada supir freelance yang memanfaatkan kemajuan infomasi dan teknologi, memanfaatkan media sosial, memiliki blog atau website yang memasarkan program tour mereka.

Pada penelitian sebelumnya, pengujian subyek dilakukan terhadap supir angkot maupun angkutan kota sehingga tidak memberikan informasi yang komprehensif dalam memahami faktor yang mempengaruhi pendapatan supir freelance, sedangkan pada penelitian ini subyek penelitiannya yang berbeda dimana penelitian ini menjelaskan karakteristik dan pengalaman dari supir freelance yang ada di Wilayah Sarbagita Provinsi Bali.

\section{METODOLOGI PENELITIAN}

Data yang digunakan dalam penelitian ini adalah data primer. Metode dan alat pengumpulan data yang digunakan adalah penyebaran kuesioner kepada responden. Yang dimaksud sebagai responden adalah Sopir freelance di Wilayah Sarbagita Provinsi Bali. Selain kuisioner dilakukan pula wawancara mendalam dengan pihak pengambil kebijakan yang berkaitan dengan transportasi dan Pariwisata. Di samping data primer juga digunakan data sekunder sebagai penunjang analisis data primer. Data sekunder tambahan untuk mendukung uraian latar belakang permasalahan penelitian yang berasal dari instansi terkait maupun dari website melalui browsing melalui internet serta dokumentasi lain, dalam penelitian ini.

Sampel dipilih dengan metode random sampling dimana tatanan pengambilan sampel supir pariwisata di Kota Denpasar, Kabupaten Badung, Tabanan dan Gianyar diambil secara acak. Penentuan jumlah sampel secara kesleuruhan ditentukan dengan metode Slovin. Dengan model estimasi:

\section{Uji Tanda Wilcoxon Sampel Besar}

Uji tanda beranking Wicoxon digunakan untuk menguji perbedaan rata-rata data berpasangan (related sample). Untuk menyelesaikan uji tanda beranking Wilcoxon yang sampelnya besar atau sama dengan 30, perhitungannya menggunakan pendekatan distribusi normal (Suyana Utama, 2014)

$Z=\frac{T-\mu_{I}}{\sigma_{I}}$

Langkah-langkah Pengujian

1) Formulasi Hipotesis

\begin{tabular}{|c|c|}
\hline $0: \mu_{\mathrm{I}} \leq \mu_{2}$ & $\begin{array}{l}\text { Pendapatan supir } \\
\text { pariwisata informal/ } \\
\text { freelance tidak menurun } \\
\text { stelah adanya transportasi } \\
\text { online dibandinkan setelah } \\
\text { adanya transportasi online }\end{array}$ \\
\hline $\mathrm{H}$ & $\begin{array}{l}\text { Pendapatan supir } \\
\text { pariwisata informal/ } \\
\text { freelance tidak menurun } \\
\text { stelah adanya transportasi } \\
\text { online dibandingkan } \\
\text { setelah adanya transportasi } \\
\text { online }\end{array}$ \\
\hline
\end{tabular}

2) Tingkat Signifikansi $0,05, \mathrm{n}=100$.

3) Kriteria Pengujian

Ho diterima bila Thitung $\geq \mathrm{T} w \alpha, 100$

Ho ditolak bila Thitung $<\mathrm{T} w \alpha, 100$

4) Perhitungan Statistik

dengan mengambil $\mathrm{T}=\sum$ Ri terkecil

5) Kesimpulan.

\section{Analisis Linier Berganda}

Analisis regresi Linier Berganda merupakan salah satu analisis yang bertujuan untuk mengetahui pengaruh suatu variabel terhadap variabel lain dimana ada hubungan secara linier antara dua atau lebih variabel independen $\left(X_{1}, \quad X_{2}, \ldots \ldots . X_{n}\right)$ dengan variabel dependen (Y). Untuk dapat mengkuantitatifkan data kualitatif yang umumnya mempunyai skala nominal maka dibuatlah variabel boneka atau yang disebut sebagai variabel dummy (Suyana Utama, 2014). Model estimasi yang digunakan ditunjukkan oleh persamaan sebagai berikut:

$\mathrm{Y}^{\prime}=\alpha-$ Jarak Akomodasi $\beta_{11}+\operatorname{tempat} \beta_{12 \mathrm{Di}}$ + modal $\beta_{2}+$ tenaga kerja $\beta_{3}+$ teknologi $\beta_{41}$ $\mathrm{Di}+$ online $\beta_{42} \mathrm{Di}+\mathrm{ei}$ 
Keterangan :

$\mathrm{Y}^{\prime}=$ pendapatan sopir pariwisata freelance (rupiah/ bulan)

Jarak = Jarak menunggu TamuMangkal Supir freelance menunggu Tamu ke tempat wisata dan akomodasi

Tempat $=$ tempat supir menunggu penumpang dengan dummy variabel (1

= Kabupaten Badung dan Kodya Denpasar, 0 = Kabupaten Gianyar dan Tabanan)

Modal = status kepemilikan kendaraan, tahun kendaraan, kapasitas kendaraan

Teknologi $=$ penggunaan IT, website dan medsos untuk mendapatkan tamu diukur dengan dummy $(1=$ menggunakan IT, medsos dan website dalam mendapatkan penumpang, $0=$ tidak menggunakan IT)

Online $=$ diukur dengan variabel dummy $(1=$ Supir bergabung dengan transportasi online, 0 = Supir tidak bergabung dengan transportasi online)

Tahapan analisis adalah sebagai berikut:

\section{Uji Kelayakan Model (Goodnes of fit)}

Pengujian statistik ini adalah pengujian model yang menyangkut ketepatan fungsi regresi sampel dalam menaksir nilai aktual dengan melihat dari Goodness of fit. Secara statistik dapat diukur dari nilai koefisien determinasi, nilai statistik $\mathrm{F}$ dan nilai statistik $\mathrm{t}$ (Imam Ghozali, 2006).

\section{Uji Parameter Model}

\section{a. Uji Signifikansi Simultan (Uji F)}

Uji statistik $F$ digunakan untuk menunjukan apakah semua variabel bebas (independen) yang dimasukan dalam model mempunyai pengaruh secara bersama-sama terhadap variabel variabel terikat (dependen) (Kuncoro, 2001 : 98). Bila nilai F dihitung lebih besar daripada $\mathrm{F}$ tabel, maka dapat dikatakan bahwa semua variabel independen secara bersama-sama mempengaruhi variabel dependen (Imam Ghozali, 2006). Untuk menguji hipotesis digunakan statistik $\mathrm{F}$ dengan pegambilan keptusan sebagai berikut (Imam Ghozali, 2005):

- Quick look : jika nilai F lebih besar daripada 4 maka $\mathrm{H}_{0}$ dapat ditolak pada derajat kepercayaan 5 persen, dengan kata lain menerima hipotesis laternatif, yang menyatakan bahwa semua variabel independen secara serentak dan signifikan mempengaruhi variabel dependen.
- Membandingkan nilai $\mathrm{F}$ hasil perhitungan dengan nilai $\mathrm{F}$ menurut tabel. Jika nilai $\mathrm{F}$ hitung lebih besar daripada nilai $\mathrm{F}$ tabel, maka $\mathrm{H}_{0}$ ditolak dan Ha diterima.

\section{b. Uji Signifikansi Parameter Individual (Uji t) \\ Uji $t$ pada dasarnya menunjuukan} seberapa jauh pengaruh satu variabel penjelas secara individual dalam menerangkan variasi variabel terikat (Kuncoro, 2001 : 97). Uji t digunakan untuk menguji signifikansi hubungan antara variabel $\mathrm{X}$ dan $\mathrm{Y}$, apakah variabel $\mathrm{X} 1$ dan $\mathrm{X} 2$ benar-benar berpengaruh terhadap individual secara individual atau parsial (Imam Ghozali, 2006). Cara melakukan uji t adalah sebagai berikut

- Quick look : jika jumlah degree of freedom (df) adalah 20 atau lebih dan derajat kepercayaan sebesar 5 persen, maka $\mathrm{H}_{0}$ dapat ditolak jika nilai $\mathrm{t}$ lebih besar dari 2 (dalam nilai absolut). Dengan kata lain menerima hipotesis laternatif, yang menyatakan bahwa semua variabel independen secara individual mempengaruhi variabel dependen.

- Membandingkan nilai t dengan titik kritis menurut tabel. Jika nilai statistik $\mathrm{t}$ hasil perhitungan lebih tinggi dibandingkan nilai t tabel, menerima hipotesis laternatif yang menyatakan bahwa semua variabel independen secara individual mempengaruhi variabel dependen.

\section{HASIL DAN PEMBAHASAN \\ Statistik Deskriptif Variabel}

Sampel yang digunakan adalah supir pariwisata informal/ freelance diwilayah Kota Denpasar, Kabupaten Badung, Gianyar dan Tabanan.jumlah sampel sebanyak 100 orang dipilih secara acak. Umur responden mayoritas adalah direntang 34-48 tahun, dengan usia termuda adalah 24 tahun dan usia tertua adalah 63 tahun. Dengan kata lain usia Supir yang menjadi responden dalam penelitian ini masih cukup produktif untuk bekerja sebagai supir.

Dari supir yang di temui dan diwawancara di obyek- obyek wisata di wilayah Sarbagita untuk keperluan penelitian ini, dilihat dari tempat tinggalnya responden sebagian besar bertempat tinggal di Denpasar sebanyak 42 persen disusul Gianyar 24 persen dan paling sedikit di Tabanan sebanyak 14 persen. 
Tabel 2. Karakteristik Sopir Informal/Freelance Menurut Tempat Tinggal

\begin{tabular}{c|c}
\hline Tempat Tinggal & Frekuensi \\
\hline Denpasar & 42 \\
Badung & 20 \\
Gianyar & 24 \\
Tabanan & 14 \\
\hline Total & 100 \\
\hline
\end{tabular}

Sumber: Data primer (data diolah), 2018

Pendapatan supir seperti terlihat di tabel 5.3 sebagian besar ada direntang Rp. 2.300.000-Rp.4.500.000 yaitu sebanyak 55 persen dari total responden. Pendapatan paling rendah yang didapatkan oleh supir perbulannya adalah sebesar Rp. 1.200.000 dan yang tetinggi adalah sebesar Rp. 10.000.000.

Tabel 3. Karakteristik Sopir Informal/Freelance Menurut Pendapatan

\begin{tabular}{c|c}
\hline Pendapatan & Frekuensi \\
\hline $\operatorname{Rp} 1.200 .000-<\operatorname{Rp~} 2.300 .000$ & 24 \\
$\operatorname{Rp~2.300.000~-~<~Rp~3.400.000~}$ & 35 \\
$\operatorname{Rp~3.400.000~-~<~Rp~4.500.000~}$ & 20 \\
$\operatorname{Rp} 4.500 .000-<\operatorname{Rp~5.600.000~}$ & 13 \\
$\operatorname{Rp~5.600.000~-~<~Rp~6.700.000~}$ & 3 \\
$\operatorname{Rp} 6.700 .000-<\operatorname{Rp~7.800.000~}$ & 1 \\
$\operatorname{Rp} 7.800 .000-<\operatorname{Rp~8.900.000~}$ & 1 \\
$\operatorname{Rp} 8.900 .000-\operatorname{Rp~10.000.000~}$ & 3 \\
\hline Total & 100 \\
\hline
\end{tabular}

Sumber: Data primer (data diolah), 2018

\section{Uji Tanda Wilcoxon Sampel Besar}

Hasil olahan data dengan program SPSS menunjukkan hasil sebagai berikut:

Npar Test Wilxoxon Signed Rank Test

Ranks

\begin{tabular}{|ll|r|r|r|}
\hline & N & Mean Rank & Sum of Ranks \\
\hline SESUDAH - SEBELUM & Negative Ranks & $89^{\mathrm{a}}$ & 47,69 & 4244,50 \\
& Positive Ranks & $4^{\mathrm{b}}$ & 31,63 & 126,50 \\
& Ties & $7^{\mathrm{c}}$ & & \\
& Total & 100 & & \\
\hline
\end{tabular}
a. SESUDAH < SEBELUM
b. SESUDAH > SEBELUM
c. SESUDAH $=$ SEBELUM 
Test Statistics ${ }^{b}$

\begin{tabular}{|l|c|}
\hline & $\begin{array}{c}\text { SESUDAH - } \\
\text { SEBELUM }\end{array}$ \\
\hline$Z$ & $-7,908^{\mathrm{a}}$ \\
Asymp. Sig. (2-tailed) &, 000 \\
\hline
\end{tabular}

a. Based on positive ranks.

b. Wilcoxon Signed Ranks Test

Hasil perhitungan Asymp. Sig (2tailed) sebesar 0,000 menunjukkan bahwa probabilitas menerima Ho jauh lebih kecil dari alpha 1 persen. Hal ini berarti Ho ditolak, sehingga dapat disimpulkan bahwa Pendapatan Supir Pariwisata Informal menurun setelah adanya Transportasi online. Jadi keberadaan Transportasi online merupakan hal yang serius dan menjadi kompetitor yang merugikan bagi supir pariwisata informal.
Secara Umum, hasil estimasi menunjukkan bahwa hampir sebagian besar Variabel bebas yang digunakan dalam model berpengaruh terhadap Pendapatan supir pariwisata informal. Berdasarkan hasil estimasi diperoleh persamaan sebagai berikut:

$$
\begin{aligned}
& \mathrm{Y}^{\prime}=-2000000-429,65^{*} \text { Jarak } \\
& \text { Akomodasi }+1015842^{*} \text { tempatDi } \\
& +85134,46 \text { tahunkend }-20517,2 \\
& \text { pengalaman } \beta_{3}-80703,1 \text { teknologi } \mathrm{Di} \\
& +2369245^{*} \text { online } \mathrm{Di}+\mathrm{ei}
\end{aligned}
$$

Tabel 4 Ringkasan Estimasi Model Regresi

\begin{tabular}{lccc}
\hline \multicolumn{1}{c}{ Variabel } & $\begin{array}{c}\text { Koefisien } \\
(\mathbf{B})\end{array}$ & t (hit) & Sig \\
\hline Jarak Akomodasi & $-429,65$ & $-2,506$ & 0,014 \\
Tempat Menunggu & 1015842 & 3,720 & 0,000 \\
Tahun Kendaraan & 85134,46 & 2,438 & 0,017 \\
Pengalaman & $-20517,2$ & $-1,176$ & 0,243 \\
Penggunaan Teknologi & $-80703,1$ & $-0,226$ & 0,822 \\
Dummy gabung Online & 2369245 & 5,679 & 0,000 \\
\hline \multicolumn{1}{c}{$\mathbf{R}^{2}$} & Df & F \\
\hline 0,535 & \multicolumn{2}{c}{17,611} \\
\hline
\end{tabular}

\section{Uji Kelayakan Model (Goodness of Fit)}

Pengujian statistik ini adalah pengujian model yang menyangkut ketepatan fungsi regresi sampel dalam menaksir nilai aktual dengan melihat dari Goodness of fit. Secara statistik dapat diukur dari nilai koefisien determinasi, nilai statistik $\mathrm{F}$ dan nilai statistik $\mathrm{t}$ (Imam Ghozali, 2005)

Uji koefisien determinasi digunakan untuk mengukur persentase variasi variabel bebas pada model regresi linier berganda dalam menjelaskan variabel terikat (Priyatno, 2008). Dari tabel 5.4 dapat dilihat nilai koefien determnasi $\left(\mathrm{R}^{2}\right)$ adalah sebesar 0,535 yang memiliki arti bahwa 53,5 persen pendapatan Supir pariwisata informal disumbangkan oleh variasi variabel bebas didalam model (variabel $\mathrm{X}$ ), sedangkan sisanya sebsar 46,65 persen dijelaskan oleh variabel lain di luar model.

\section{Uji Parameter Model}

\section{Uji Signifikansi Simultan (Uji F)}

Uji statistik $F$ digunakan untuk menunjukan apakah semua variabel bebas (independen) yang dimasukan dalam model mempunyai pengaruh secara bersama-sama terhadap variabel Pendapatan supir pariwisata informal. Secara quick look dapat dilihat nilai 
F sebesar 17,611 lebih besar daripada 4 maka $\mathrm{H}_{0}$ dapat ditolak pada derajat kepercayaan 5 persen, dengan kata lain menerima hipotesis alternatif, yang menyatakan bahwa semua variabel independen jarak menunggu tamu ke akomodasi wisata, wilayah menunggu tamu, tahun kendaraan yang digunakan, pengalaman, penggunaan teknologi dan bergabung dengan Transportasi online secara serentak dan signifikan mempengaruhi Pendapatan supir pariwisata informal di Wilayah Sarbagita.

\section{Uji Signifikansi Parameter Individual (Uji t) \\ Uji $t$ pada dasarnya menunjukkan} seberapa jauh pengaruh satu variabel penjelas jarak menunggu tamu ke akomodasi wisata, wilayah menunggu tamu, tahun kendaraan yang digunakan, pengalaman, penggunaan teknologi dan keikutsertaan menjadi Transportasi online secara individual dalam menerangkan variasi variabel terikat Pendapatan Supir Pariwisata informal. Uji $t$ dilakukan untuk menguji signifikansi hubungan antara variabel bebas (X) dan variabel terikat $(\mathrm{Y})$, apakah variabel $\mathrm{X} 1$, $\mathrm{X} 2, \mathrm{X} 3, \mathrm{X} 4$ dan $\mathrm{X} 5$ benar-benar berpengaruh terhadap individual secara individual atau parsial (Imam Ghozali, 2006). Secara quick look, jumlah degree of freedom (df) penelitian ini adalah 92 lebih besar dari 20 sehingga dengan derajat kepercayaan sebesar 5 persen, maka $\mathrm{H}_{0}$ dapat ditolak jika nilai t lebih besar dari 2 (dalam nilai absolut). Dengan kata lain menerima hipotesis alternatif, yang menyatakan bahwa semua variabel independen secara individual mempengaruhi variabel dependen.

Dalam penelitian ini sebagian besar nilai $\mathrm{t}$ lebih besar dari 2 (dalam nilai absolut) yaitu jarak menunggu tamu ke akomodasi wisata $(2,506)$, wilayah menunggu tamu $(3,720)$, tahun kendaraan $(2,438)$ dan keikutsertaan supir Pariwisata informal bergabung dengan transportasi online $(2,438)$. Sedangan variabel pengalaman kerja dan penggunaan teknologi tidak berpengaruh signifkan secara parsial terhadap Pendapatan Supir Pariwisata informal.

Variabel jarak menunggu tamu ke akomodasi wisata berpengaruh signifikan terhadap Pendapatan Supir Pariwisata informal, nilai koefisien sebesar $-429,65$ memiliki arti bahwa jika jarak menunggu tamu bertambah satu meter dengan asumsi variabel lain konstan maka pendapatan akan berkurang sebesar Rp.429,65. Dengan kata lain jika jarak menunggu tamu bertambah satu meter maka pendatan akan berkurang sebanyak Rp. 429,65 .

Dummy Variabel wilayah menunggu tamu berpengaruh signifikan terhadap Pendapatan Supir Pariwisata informal dengan nilai koefisien sebesar 1015842 memiliki arti bahwa pendapatan Supir pariwisata informal di wilayah Kota Denpasar dan Kabupaten Badung lebih tinggi Rp 1.025 .842 dibandingkan dengan di Kabupaten Gianyar dan Tabanan.

Variabel tahun kendaraan yang digunakan berpengaruh signifikan terhadap Pendapatan Supir Pariwisata informal dengan nilai koefisien sebesar 85134,46 memiliki makna dengan asumsi variabel lain konstan jika tahun kendaraan bertambah satu tahun maka pendapatan Supir Pariwisata informal bertambah sebesar Rp. 85.134,56. Dengan kata lain jika umur kendaraan lebih muda sat tahun akan menambah pendapatan supir pariwisata freelance sebesar Rp. 85.134,56.

Variabel pengalaman berpengaruh tidak signifikan secara parsial terhadap Pendapatan Supir Pariwisata informal dengan koefisien -20517,2 memiliki makna jika pengalaman Supir Pariwisata informal/ freelance bertambah 1 tahun akan mengurangi pendapatan sebesar rp. 205.517,2 dengan asumsi variabel lain konstan

Variabel dummy penggunaan teknologi juga berpengaruh tidak siginifikan secara parsial terhadap Pendapatan Supir Pariwisata informal dengan koefisien sebesar -80703,1 memiliki arti bahwa Supir pariwisata freelance yang menggunakan teknologi informasi, sosial media dan internet dalam mendapatkan tamu lebih rendah pendapatannya sebesar $\mathrm{Rp}$ $80.703,1$ dibandingkan dengan yang tidak menggunkan teknologi informasi, sosial media dan internet.

Dummy Variabel bergabung dengan Transportasi online berpengaruh signifikan terhadap Pendapatan Supir Pariwisata informal dengan nilai koefisien sebesar 2369245 memiliki arti bahwa Supir pariwisata informal yang memutuskan bergabung dengan transportasi online pendpatannya lebih tinggi Rp 1.025.842 dibandingkan dengan supir pariwisata informal yang tidak bergabung dengan transportasi online. 
Analisis Pendapatan Supir Pariwisata informal Pasca transportasi online

Hasil studi menunjukkan terdapat penurunan signifikan pendapatan supir pariwisata informal/ freelance setelah munculnya transportasi online. Munculnya transportasi online dengan segala kemudahan yang diberikan kepada konsumennya menyebabkan konsumen berpaling menggunakan moda tranportasi ini dan meninggalkan transportasi konvensional sebelumnya. Harga yang kompetitif, layanan yang cepat dan kemudahan dalam mengakses sehingga transportasi online sangat cepat dan mudah diterima oleh masyarakat termasuk wistawan yang sedang berkunjung ke Bali. Wisatawan dengan adanya pilihan transportasi ini mulai meninggalkan moda transportasi yang lama.

Supir pariwisata informal/ freelance termasuk yang paling terkena imbas dari munculnya moda transportasi online. Ditengah persaingan yang sudah sangat ketat antar sesama supir freelance, taxi, angkutan travel, angkutan hotel, bemo ditambah munculnya transportasi online menyebabkan mereka semakin terdesak, kesulitan mendapatkan penumpang dan hampir kehilangan mata pencahariannya. Hal ini jika dibiarkan dan tidak dicarikan solusi yang tepat selain menambah angka pengangguran di Bali juga rentan menimbulkan gesekan antara tarnsportasi online dan konvensional.

Pemerintah sebaiknya memediasi keberadaan supir freelance ini dengan mengatur kembali Permenhub No 108/2017 tentang transportasi online 1) mengatur wilayah operasi sehingga tidak berebut lahan dengan supir freelance maupun transportasi lainnya, 2) menetapkan dan mempublikasi kuota angkutan online yang sesuai dengan kebutuhan konsumen sehingga tidak mematikan angkutan lain, 3) transportasi online harus menggunakan tanda nomor kendaraan bermotor TNKB sesuai wilayah operasi yang ditetapkan sehingga tidak menimbulkan tumpang tindih dengan transportasi yang sudah ada sebelumnya dan kebocoran PAD Bali, tidak jarang ditemui transportasi online menggunakan plat kendaraan luar Bali dan beroperasi di Bali. Hal ini tidak hanay merugikan pelaku usaha di Bali tetapi juga merugikan perekonomian daerah.

\section{Pengaruh Tempat menunggu tamu terhadap Pendapatan supir pariwisata informal/ freelance}

Tempat menunggu tamu pada studi ini berpengaruh secara signifikan terhadap pendapatan supir pariwisata informal. Tempat menunggu dilihat dari jarak menunggu tamu berpengaruh signifikan dan negatif. Semakin jauh posisi menunggu mereka dari akomodasi hotel dan restaurant, obyek wisata (pantai, Pura, danau dan lain lain) dan Bandara Udara maka pendapatan mereka akan semakin berkurang. Sebaliknya semakin dekat jarak menunggu maka pendapatan mereka akan bertambah. Jarak terdekat mereka menunggu tamu tumpangan 10 meter dan jarak terjauh adalah 3000 meter. Hal ini sudah menjadi kebiasaan wisatawan menginginkan kemudahan dalam segala hal dalam kunjungan mereka, termasuk untuk kebutuhan jasa transportasi biasanya mereka menginginkan kepraktisan dan cenderung menggunakan transportasi yang dekat dari jangkaun mereka.

Dummy variabel wilayah supir menunggu tamu berpengaruh positif dan signifikan. Hasil stui menunjukkan pendapatan supir di Denpasar dan Badung lebih tinggi dibandingkan dengan di Kabupaten Gianyar dan Tabanan. Sampel yang diambil dalam studi ini 59 persen wilayah menunggu wisatawan berada di Kota Denpasar dan Badung sedangkan 41 persennya mencari nafkah di Kabupaten Gianyar dan Tabanan. Mereka mendapatkan pendapatan lebih besar karena akomodasi wisata lebih terkonsentrasi di Bali selatan yaitu Denpasar dan Badung, sehingga tamu yang menginap disana lebih mudah mengakses mereka. Di Tabanan yang memiliki banyak potensi obyek wisata seperti Bedugul, Jatiluwih, Alas Kedaton dan Tanah Lot cenderung hanya menjadi daerah tujuan, biasanya wisatawan sudah mendapatkan supir didekat hotel tempat mereka menginap. Mereka biasanya mendapatkan wisatawan yang melakukan one way trip karena menginginkan waktu yang lama disuatu obyek wisata, sehingga ditinggal oleh supirnya di lokasi obyek wisata.

\section{Pengaruh tahun kendaraan terhadap Pendapatan supir pariwisata informal/ freelance}

Hasil Penelitian menunjukkan Tahun kendaraan berpengaruh negatif dan signifikan 
yang berarti semakin bertambah tahun kendaraan maka pendapatan supir pariwisata freelance akan semakin bertambah, dengan kata lain semakin muda umur kendaraan akan meningkatkan pendapatan supir pariwisata freelance. Kepemilikan mobil sebagai salah satu modal kongkret dapat digunakan sebagai proses produksi untuk menghasilkan pendapatan.Semakin baru mobil yang digunakan oleh supir freelance menunjukkan semakin banyak modal yang digunakan dalam proses produksi. Semakin besar modal yang digunakan digunakan dalam proses produksi semakin besar penghasilan yang akan diperoleh.

Mobil yang lebih muda tahun produksinya baru umumnya akan lebih rapi dan bersih dibandingkan dengan yang tahun pembuatannya lebih tua. Wisatawan dalam pelayanannya umumnyanya menginginkan pelayanan yang ramah dan kendaraan yang wangi, rapi dan bersih.

\section{Pengaruh pengalaman terhadap Pendapatan supir pariwisata informal/ freelance}

Pengalaman yang diukur dari lama supir pariwisata informal/ freelance menjalankan profesinya sebagai supir pariwisata informal/ freelance berpengaruh negative dan tidak signifikan terhadap pendapatannya. Jadi semakin berpengalaman atau semakin lama mereka menjadi supir malah mengurangi pendapatannya.

Pekerja yang semakin berpengalaman biasanya akan semakin berumur. Produktivitas tenaga kerja biasanya dititik awal akan naik, namun pada titik tertentu akan semakin menurun, dari responden yang terpilih secara acak terdapat 17 orang sudah yang berumur diatas 50 tahun.

\section{Pemanfaatan teknologi terhadap Pendapatan supir pariwisata informal/ freelance}

Penggunaan internet dan media sosial berpengaruh negatif dan tidak signifikan terhadap pendapatan supir pariwisata informal/ freelance. Hal ini disebabkan oleh karena penggunaan media internet (website, blog) dan media sosial (facebook, whatsapp, instagram) belum digunakan secara optimal dan profesional dalam pekerjaannnya untuk mendapatkan konsumen.
Supir pariwisata informal/ freelance yang memiliki inisistif bergabung bergabung dengan Transportasi online dari hasil penelitian ternyata memiliki pendapatan lebih tinggi dibandingkan dengan yang tidak bergabung. Segala kemudahan, harga yang kompetitif/ murah dan kemudahan mengakses menyebabkan transportasi online lebih mudah mendapatkan penumpang sehingga pendapatannya menjadi meningkat. Dari sampel yang diambil secara acak untuk keperluan penelitan hanya 10 persen dari mereka yang memilih bergabung dengan transportasi online, sedangkan 90 persen lainnya memilih tidak bergabung dengan transportasi online dengan berbagai alasan. Seperti yang disampaikan salah supir freelance (Tony, 2018) mengatakan:

"Saya tidak mau ikut menjadi supir go car karena sudah cukup nyaman menjadi supir freelance. harga tarif go car terlalu murah sehingga kalau bergabung seperti melakukan kerja bakti, capek gak jelas tanpa pendapatan yang cukup. Ongkos nyupir habis hanya untuk membeli bensin. Capek mondar-mandir dijalan hanya menghabiskan bensin."

Sebagian besar supir freelance hampir memberikan alasan yang sama yang mengatakan mereka tidak mau bergabung ke transportasi online karena tarif go Car yag sangat murah dan tidak sesuai standar sehingga hanya cukup untuk menutup biaya bahan bakar kendaraan. Tarif transportasi online yang dihitung tetap/flat berdasarkan jarak kilometer tanpa memandang kemacetan dianggap oleh mereka sangat murah dan mengundang kecemburuan bagi supir freelance dan moda transportasi lainnya.

Pemerintah atau instansi terkait sebaiknya menjadi mediasi, dengan meninjau kembali Permenhub No 108/2017 yang mengatur tentang taxi daring, terutamanya menaikkan besaran tarif batas bawah, sehingga operasional transportasi online tidak sampai mematikan transportasi konvensional. Jika hal ini dilakukan niscaya tidak hanya bisa menghindarkan bentrokan antara transportasi online dengan transportasi lain yang sudah ada sebelumnya, tetapi juga mengundang transportasi lain untuk berkolaborasi dan memanfaatkan inovasi teknologi yang disediakan provider transportasi online. 
Perubahan moda transportasi akibat perkembangan teknologi yang pesat merupakan sesuatu yang tidak dapat dihindari, kemajuan teknologi yang ada seharusnya dimanfaatkan sehingga bukan merupakan ancaman tetapi seharusnya menjadi peluang untuk menambah pendapatan.

\section{SIMPULAN}

Pendapatan supir pariwisata informal/ freelance terdapat penurunan signifikan setelah munculnya transportasi online. Identifikasi terhadap variabel yang dapat meningkatkan pendapatan supir freelance diharapkan memberi gambaran kepada berbagai pihak dan dapat digunakan sebagai referensi dalam pengambilan keputusan. Pengambilan kebijakan oleh dinas terkait dapat disesuaikan dengan hasil temuan sehingga penerapan kebijakan bisa berjalan optimal. 


\section{Kepustakaan}

BPS Bali, 2016, Bali Dalam Angka.

Dinas Pariwisata Provinsi Bali, 2016, Statistik Pariwisata Bali.

Jhingan, M.L. 2000, Ekonomi Pembangunan dan Perencanaan, terjemahan D. Guritno, Ed.1 Cet. 8, PT. RajaGrafindo Persada, Jakarta.

Hasbianto, Indra,2015, Analisis Pendapatan Sopir Angkutan Kota di Surakarta, Skripsi Universitas Sebelas Maret, Surakarta.

Jura, Desnal Christian, 2015, Pengaruh harga BBM dan Jumlah Penumpang Terhadap Pendapatan Sopir Angkot Di Kota Manado Tahun 2015 (Studi P ada Trayek 02/Malalayang), e-journal.unstrat.ac.id. Manado.

Reksoprayitno,Soediyono, Pengantar Ekonomi Mikro Edisi Milenium, Cetakan 1 , BPFE, Yogyagkarta.
Siswanto, Dwi, 2013, Faktor- Faktor Yang Mempengaruhi Pendapatan Supir Angkutn Pedesaan Terminl Arjasa Jember, skripsi Fakultas Ekonomi dan Bisnis Universitas Jember.

Sugiarto, dkk, 2005, Ekonomi Mikro Sebuah Kajian Komprehensif, Ed. 2 Cet. 3, PT Gramedia Pusaka Utama, Jakarta.

Sukirno, Sadono, 2002, Teori Mikro Ekonomi. Cet. 14, Rajawali Press, Jakarta.

Suyana Utama, 2009, Aplikasi Kuantitatif, Ed. 3, Fakultas Ekonomi dan Bisnis, Denpasar.

Todaro, Michael P., 2000, Pembangunan Ekonomi Di Dunia Ketiga, Jilid 1dan 2, Erlangga, Jakarta.

Yoeti, Oka A. 2001, Tours and Travel Management, Edisi 6, PT Pradnya Paramita, Jakarta.

https;//m.cnninonesia.com diunduh 8 februari 2018,13.29. 